\title{
Hydrogen economy in Taiwan and biohydrogen
}

\author{
Duu-Hwa Lee ${ }^{a, *}$, Duu-Jong Lee ${ }^{b}$ \\ ${ }^{a}$ Department of Economics, Aletheia University, No. 32, Chen-Li Street, Taipei 251, Taiwan, ROC \\ ${ }^{b}$ Department of Chemical Engineering, National Taiwan University, No. 1, Section 4, Roosevelt Road, Taipei 106, Taiwan, ROC
}

\section{A R T I C L E I N F O}

Article history:

Received 19 June 2007

Accepted 28 September 2007

Available online 19 November 2007

Keywords:

Hydrogen economy

Biohydrogen

Taiwan

$\mathrm{CO}_{2}$ emission

\begin{abstract}
A B S T R A C T
This study analyzed how production technology advances and how economic structure reformation affects transition to a hydrogen economy in Taiwan before 2030. A model, called "Taiwan general equilibrium model-energy, for hydrogen (TAIGEM-EH)", was the forecast tool used to consider steam reforming of natural gas, the biodegradation of biomass and water electrolysis using nuclear power or renewable energies of hydrogen production industries. Owing to increase in the prices of oil and concern for global warming effects, hydrogen will have a 10.3\% share in 2030 when demands for hydrogen production could be met if strong technological progress in hydrogen production were made. With reformed economic structure and strong support to progress in production technologies, hydrogen's share can reach $22.1 \%$ in 2030 and become the dominating energy source from then onwards. In the four scenarios studied, including developing country with three levels of effort and developed country with strong effort, the biohydrogen production industry can become a main supplier of hydrogen in the market if its technological progress can be competitive to other $\mathrm{CO}_{2}$-free alternatives.
\end{abstract}

c 2007 International Association for Hydrogen Energy. Published by Elsevier Ltd. All rights

reserved.

\section{Introduction}

Obstacles to the transition from a petroleum to hydrogen economy include the lack of a reliable and sufficient supply of hydrogen [1,2]. The steam reforming of natural gas, the biodegradation of biomass and water electrolysis using nuclear power or renewable energies, herein referred to as NG- $\mathrm{H}_{2}$, bio- $\mathrm{H}_{2}$, nuclear $-\mathrm{H}_{2}$ and renewables $-\mathrm{H}_{2}$, are used in industrial hydrogen production. Biohydrogen has been produced from biomass using biological and photobiological approaches [3,4] as a clean energy source without greenhouse gas emission [5,6]. The International Energy Agency has commented that biohydrogen is now a weak technology but with high market potential [7].

An analysis of various economic development scenarios can help decision makers identify their optimal strategy for achieving economic targets. This study presents an economywide analysis of how technology advances and how an improvement in the economic structure is accelerating Taiwan's transition to a hydrogen economy before 2030. A model, called "Taiwan general equilibrium model-energy, for hydrogen (TAIGEM-EH)", which is derived from ORANI [8] and MONASH $[9,10]$ models by Monash University in Australia, is a dynamic, linearized percentage change forecast tool used especially in the economic evaluation of environment policies. The critical factors that affect economic growth rates, $\mathrm{CO}_{2}$ emission rates, possible adverse effects of inertial barriers of oil price hikes and difficulty of energy substitution in the present economic structure were discussed.

\section{Model \\ 2.1. Basic model \\ The TAIGEM-EH model has been described elsewhere [11-16]. A brief description of the model, and particularly the role of}

\footnotetext{
*Corresponding author. Tel./fax: +886226258024.

E-mail addresses: au4218@email.au.edu.tw (D.-H. Lee), djlee@ntu.edu.tw (D.-J. Lee).
} 0360-3199/\$ - see front matter ๔ 2007 International Association for Hydrogen Energy. Published by Elsevier Ltd. All rights reserved. doi:10.1016/j.ijhydene.2007.09.028 
hydrogen production-related industries, is presented as follows.

TAIGEM-EH is the most comprehensive model available for Taiwan's economy, which consists of 170 sectors, six types of labor, eight types of margin and 182 commodities. The assumption of input-output separability for model simplification implies the generalized production function for some industries: $F$ (inputs, output) $=0$ can be written as: $G$ (inputs) $=$ Activity $=H$ (outputs). The $H$ function is derived from two nested constant elasticity of transformation (CET) [17] aggregation functions, while the $G$ function is broken into five nested constant elasticity of substitutions (CES) [18]. Each nested CES structure displays the optimization problem that firms choose cheapest input combination to minimize total cost subject to the CES production technology. Each nested CET structure displays the optimization problem that distributors choose optimal output combination to maximize total profit subject to the CET production transformation ratio. CET is identical to $\mathrm{CES}$, except that the transformation parameter in the CET function has an opposite sign to the substitution parameter in the CES function. The nested structure displayed in Fig. 1 shows multi-input and multioutput production specifications. The input demand for industry production is represented as a five-level nested structure, and the operation of each level is decided independently. On the top level, commodity composites and a primary-factor composite are combined using a Leontief production function. Therefore, the demand is directly proportional to the industry activity. On the second level, each commodity composite is represented using a CES function incorporating domestic supply and imported equivalents [19]. The energy and primary-factor composites are CES aggregates of energy composites and primary-factor composites. On the third level, the primary-factor composite is a CES aggregation of labor, land, capital and the energy composite. The energy composite is modeled as a CES aggregate of hydrogen, coal products, oil products, natural gas products and electricity. On the fourth level, the coal product composite is a CES aggregation of coal and coal products; the oil product composite is a CES aggregation of gasoline, diesel oil, fuel oil and kerosene; the natural gas product composite is a CES aggregation of refinery gas, gas and natural gas; and a hydrogen composite is a CES aggregation of $\mathrm{NG}-\mathrm{H}_{2}$, bio- $\mathrm{H}_{2}$, nuclear- $\mathrm{H}_{2}$ and renewables- $\mathrm{H}_{2}$. On the bottom level, energy and hydrogen are a CES aggregation of domestic and imported supplies. In the output level, CET profit maximization behavior demonstrates how industry outputs transform to commodity outputs in the first level, and also presents how a distributor decides to sell a commodity to the local or export market in the second level.

The power sector of TAIGEM-EH is modeled as a technology bundle (Fig. 2) derived from the MEGABARE model developed by Australian Bureau of Agricultural and Resource Economics (ABARE) [20], which is composed of 10 power generation technologies, namely hydro, stream turbine oil, stream turbine coal, stream turbine gas, combined cycle oil, combined cycle gas, gas turbine oil, gas turbine gas, diesel and nuclear. The power sector is able to switch between different power technologies in response to changes in their relative costs through the CES production function. The output of the end-use electricity is a minimized cost behavior subject to a CES aggregate of each electricity technology. All electricity thus generated is sent to end-users.

\subsection{Database}

The database for TAIGEM-EH model is presented in the IO table [21] (Fig. 3). Column data in the table denote the "supply side" and the row data represent the "demand side". It shows that aggregate supply is equaled to aggregate demand for the entire economy equilibrium. Supply side includes intermediate and primary input for industries, demand side includes intermediate demand for industries and final demand for household consumption, government expenditure, investment and net export.

\subsection{Model parameters}

The production of hydrogen requires intermediate inputs (such as biomass and/or natural gas as raw materials and nuclear, wind and solar energy sources) and primary inputs (labor, capital and machinery). A historical data set for hydrogen-related industries in Taiwan was obtained to prepare the balanced IO table to formulate hydrogen supply and demand chains. The survey data on these supplydemand chains were collected from gas companies, professional clubs, specialists and articles [22-31]. The relative power generation costs of 10 power generation sectors were obtained from Taiwan Power Company (TPC) [32,33].

The annual recursion of the status of all 170 sectors was simulated. Individual sectors try to minimize their costs (film agents) to meet production/consumption needs or to maximize utility efficiency (household agents) because of budget constraints. The outputs of the model are the "optimal" states of all agents in the economic body of the "demand equals supply" criterion. In the simulation, all nonlinear relationships were linearized to reduce computational effort. The TAIGEM-EH acquires a historical database of supplies and demands in all sectors of Taiwan. Table 1 presents exogenous shocks in the forecast of the petroleum economy baseline from 2006 to 2030 according to a national economic report provided by Directorate-General of Budget, Accounting and Statistics (DGBAS) [34] and the results are summarized as follows.

(1) The annual growth rate in the number of households is $2 \%$ from 2006 to 2030, reflecting Taiwan's currently low population growth rate.

(2) The energy and productivity efficiency improvement rates are $1.2 \%$ and $2.5 \%$ annually, indicating the advantages provided by advances in energy technologies and production technologies.

(3) The rate of increase of employment is $1 \%$, which corresponds to the population growth rate.

(4) The CPI will be $2 \%$ annually.

(5) The price of imported petroleum increased by $27.4 \%$ in 2004 and by $38.9 \%$ in 2005 . It will continue to rise at a pace of $3.21 \%$ onwards until 2030 , based on the high oil price projection of EIA's forecast [35].

(6) The rate of tariff decline meets WTO regulations until 2010. 


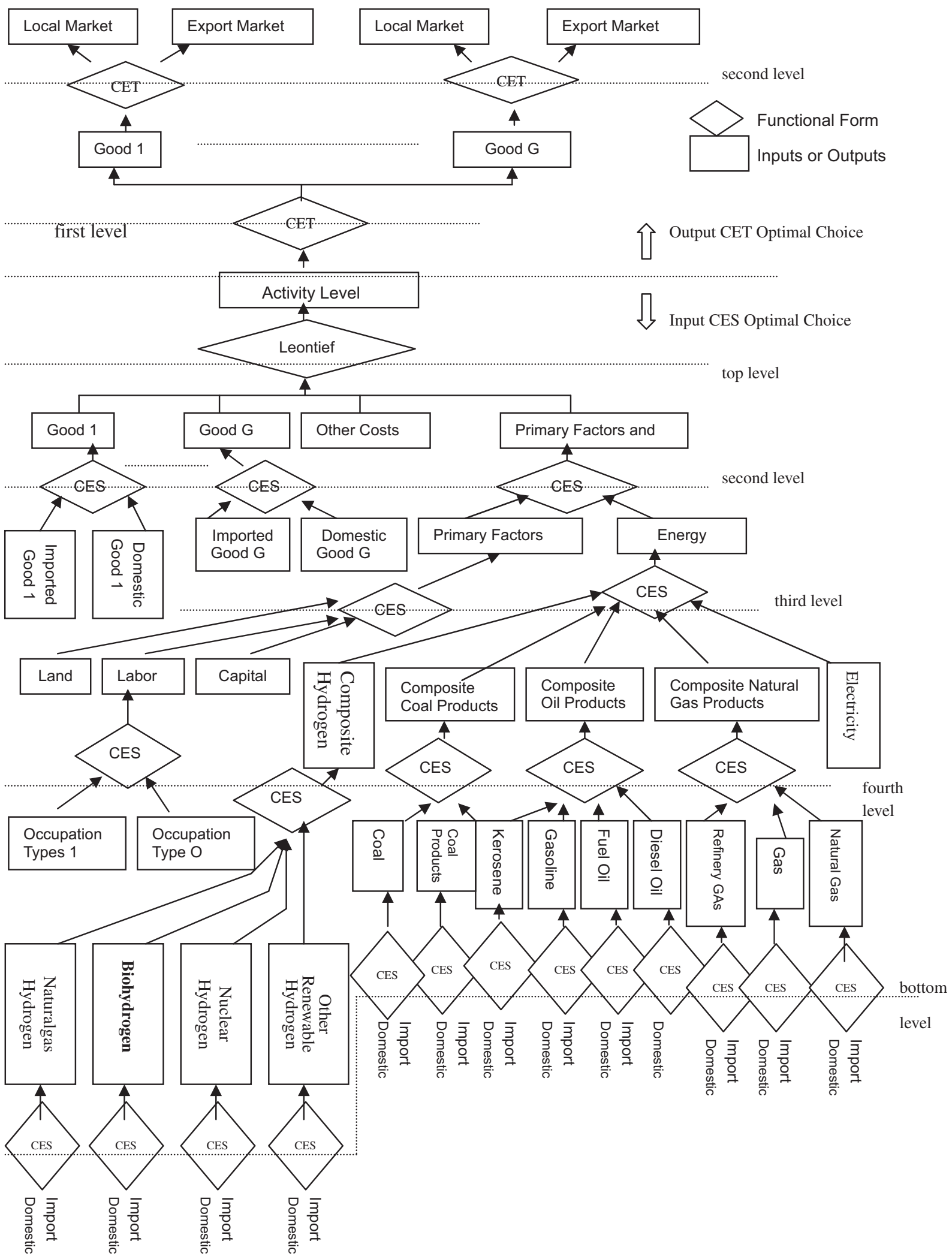

Fig. 1 - Structure of production function: non-electricity sectors.

Table 2 presents the relative costs of various hydrogen production sub-sectors obtained from a recent survey conducted by the Taiwan Institute of Economic Research. The cost of producing hydrogen from natural gas is the lowest among the four sub-sectors, corresponding to its current popularity. The cost of bio- $\mathrm{H}_{2}$ is lower than those of nuclear- $\mathrm{H}_{2}$ and renewables- $\mathrm{H}_{2}$. 


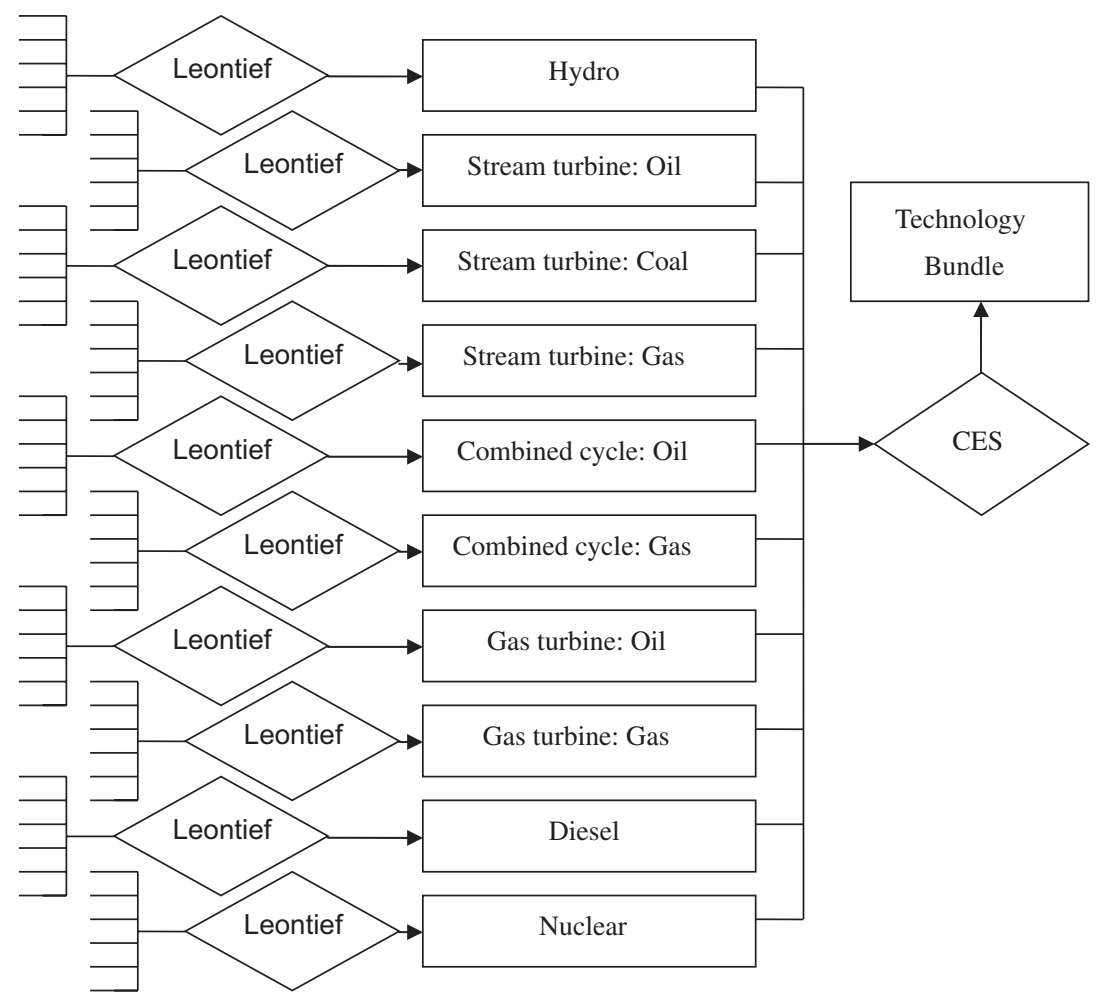

Fig. 2 - The technology bundle of TAIGEM-EH model for electricity sectors.

\begin{tabular}{|c|c|c|c|c|c|c|c|c|}
\hline & \multicolumn{7}{|c|}{ Absorb Matrix } \\
\hline & & 1 & 2 & 3 & 4 & \multicolumn{2}{|c|}{5} & 6 \\
\hline & & Producer & Investor & Household & Export & \multicolumn{2}{|c|}{ Government } & Inventory \\
\hline & Dimension & I & 1 & 1 & 1 & \multicolumn{2}{|c|}{1} & 1 \\
\hline Basic Flow & $\mathrm{C} \times \mathrm{S}$ & V1BAS & V2BAS & V3BAS & V4BAS & V5BAS & & \multirow[t]{2}{*}{ VGBAS } \\
\hline Tax & $\mathrm{C} \times \mathrm{S}$ & VITAX & \multicolumn{2}{|l|}{ V2TAX } & V4TAX & \multicolumn{2}{|c|}{ V5TAX } & \\
\hline Labor & $\mathrm{O}$ & VILAB & \multirow{5}{*}{\multicolumn{3}{|c|}{$\begin{array}{l}\mathrm{I}=\text { Industry } \\
\mathrm{C}=\text { Commodity } \\
\mathrm{S}=\text { Domestic or Imported } \\
\mathrm{O}=\text { Occupation } \\
\text { Bads = commodity emits } \mathrm{CO}_{2}\end{array}$}} & & & \\
\hline Capital & 1 & VICAP & & & & & & \\
\hline Land & 1 & VILND & & & & & & \\
\hline Other Cost & 1 & V1OCT & & & & & & \\
\hline & & & & & & & & \\
\hline & & & Produce & & & Capital & Acc & cumulation \\
\hline & & Dimension & I & & & Dimension & & 1 \\
\hline & & Bads*S & $\mathrm{CO}_{2}$ Emiss & & & I & & STOK \\
\hline & & & Productio & & & & & Tariff \\
\hline & & Dimension & I & & & Dimension & & 1 \\
\hline & & $\mathrm{C}$ & MAKE & & & $\mathrm{C}$ & & VOTAR \\
\hline
\end{tabular}

Fig. 3 - Input-output database for TAIGEM-EH model.

An energy balance sheet was used to estimate a $\mathrm{CO}_{2}$ emission matrix from 15 emission commodities, including coal, natural gas, other non-metallic minerals, gasoline, diesel fuels, aviation fuels, fuel oils, kerosene, lubricants, naphtha, refinery gases, asphalt, other refining products, coal products and gas. The production of $\mathrm{CO}_{2}$ is penalized in production/consumption functions through the carbon tax policy. Clean energy sources such as bio- $\mathrm{H}_{2}$, which does not emit net $\mathrm{CO}_{2}$, are encouraged given cost saving considerations.

\subsection{Scenario design}

A developed country is in an economic maturity stage; restated, it is classified under the so-called "neo-classical" long-run assumption in economics. A developing country is on the other hand under the "Keynesian" short-run assumption, in that, in the economic growing stage, resource reallocation is not so flexible. Taiwan is a developing country. The present Scenarios I-III adopted the Keynesian short-run closure for simulating the current situation of Taiwan, while 


\section{Table 1 - Exogenous shocks for forecasting baseline: from 2000 to 2030}

\begin{tabular}{|c|c|c|c|c|c|c|c|}
\hline Macroeconomic variables growth rate (\%) & 2000 & 2001 & 2002 & 2003 & 2004 & 2005 & 2006-2030 \\
\hline Energy-saving decline rate & -0.60 & -0.60 & -1.20 & -1.20 & -1.20 & -1.2 & -1.20 \\
\hline Real GDP & 5.78 & -2.17 & 3.94 & 3.33 & 5.71 & 4.09 & Endog. \\
\hline Imports & 4.54 & -13.5 & 5.71 & 6.72 & 18.60 & 3.90 & Endog. \\
\hline Household consumption & 4.84 & 1.00 & 2.07 & 0.84 & 3.13 & 4.81 & Endog. \\
\hline Export & 18.1 & -8.08 & 10.5 & 10.9 & 15.3 & 4.77 & Endog. \\
\hline Investment & 8.38 & -21.1 & -1.61 & -2.05 & 15.4 & -0.43 & Endog. \\
\hline Government expenditure & 0.28 & -0.55 & 1.47 & 0.71 & -0.69 & 1.98 & Endog. \\
\hline Number of households & 2.28 & 1.80 & 1.80 & 1.76 & 1.75 & 1.57 & 2.00 \\
\hline Employment trend & 1.20 & 0.49 & 1.13 & 1.07 & 2.11 & 1.59 & 1.00 \\
\hline Aggregate price index & -1.80 & 0.51 & -0.89 & -2.21 & -1.92 & -0.70 & Endog. \\
\hline Exchange rate & -5.15 & 6.00 & -1.29 & 0.49 & 2.87 & 3.76 & Endog. \\
\hline Imports price index (c.i.f.) & -4.62 & 1.34 & -1.25 & 2.98 & 8.57 & 2.42 & Endog. \\
\hline Exports price index & 0.87 & 0.77 & 0.32 & -0.87 & 1.61 & -2.45 & Endog. \\
\hline Primary-factors productivity & Endog. & Endog. & Endog. & Endog. & Endog. & Endog. & -2.50 \\
\hline Consumer price index & Endog. & Endog. & Endog. & Endog. & Endog. & Endog. & 2.00 \\
\hline The energy structure & Endog. & Endog. & Endog. & Endog. & Endog. & Endog. & Endog. \\
\hline Industrial structure & Endog. & Endog. & Endog. & Endog. & Endog. & Endog. & Endog. \\
\hline Labor (primary factor) demand & \multicolumn{7}{|c|}{ Labor is a CES aggregation of various types of labor forces } \\
\hline Price of petroleum & \multicolumn{7}{|c|}{$\begin{array}{l}\text { The price of imported petroleum increased by } 4.96 \% \text { in } 2002,13.94 \% \text { in } 2003 \text {, } \\
27.40 \% \text { in } 2004,38.91 \% \text { in } 2005 \text { and was assumed to increase by } 3.21 \% \text { onwards } \\
\text { up to } 2030 \text {, based on high oil price projection of EIA [35] forecast. }\end{array}$} \\
\hline Technology bundle & \multicolumn{7}{|c|}{$\begin{array}{l}\text { Substitution elasticity of hydro is } 0.1 \text {, nuclear power } 1.0 \text {, coal } 0.1 \text {, oil } 0.5 \text { and } \\
\text { natural gas } 0.5\end{array}$} \\
\hline Ascension to WTO & \multicolumn{7}{|c|}{$\begin{array}{l}\text { Taiwan joined WTO in 2002. The tariff decline rate was assumed to in } \\
\text { conformance to WTO rules up to } 2010\end{array}$} \\
\hline A developed and a developing country elasticities setting & \multicolumn{7}{|c|}{$\begin{array}{l}\text { Different CES elasticities are adopted in the simulation: four hydrogen }(0.8 / 0.4) \text {, } \\
\text { other energy sources }(1.0 / 0.5) \text {, primary inputs }(0.8 / 0.4) \text { and transformation }(0.8 / 0.4)\end{array}$} \\
\hline
\end{tabular}

Table 2 - Cost share for different kinds of hydrogen production

\begin{tabular}{|c|c|c|c|c|c|c|c|c|}
\hline & \multicolumn{2}{|c|}{$\begin{array}{l}\text { Natural gas steam } \\
\text { reforming }\end{array}$} & \multicolumn{2}{|c|}{ Biohydrogen } & \multicolumn{2}{|c|}{ Nuclear hydrogen } & \multicolumn{2}{|c|}{$\begin{array}{c}\text { Other renewable } \\
\text { hydrogen }\end{array}$} \\
\hline & Input & $\mathrm{USD} / \mathrm{m}^{3}$ & Input & $\mathrm{USD} / \mathrm{m}^{3}$ & Input & $\mathrm{USD} / \mathrm{m}^{3}$ & Input & $\mathrm{USD} / \mathrm{m}^{3}$ \\
\hline \multirow[t]{4}{*}{$\begin{array}{l}\text { Inter-mediate } \\
\text { input }\end{array}$} & Natural gas & 0.1 & $\begin{array}{l}\text { Biomass and } \\
\text { waste }\end{array}$ & 0.17 & $\begin{array}{l}\text { Nuclear } \\
\text { material }\end{array}$ & 0.07 & Water & 0.13 \\
\hline & Catalyst & 0.03 & Catalyst & 0.03 & $\begin{array}{l}\text { Chemical } \\
\text { material }\end{array}$ & 0.03 & & \\
\hline & Electricity & 0.03 & Electricity & 0.03 & Electricity & 0.03 & & \\
\hline & Steam & 0.03 & Steam & 0.03 & & & & \\
\hline \multirow[t]{8}{*}{ Primary input } & Wage & 0.1 & Wage & 0.13 & Wage & 0.07 & Wage & 0.07 \\
\hline & Depreciation & 0.07 & Depreciation & 0.07 & Depreciation & 0.13 & Depreciation & 0.17 \\
\hline & Rent of land & 0.03 & Rent of land & 0.03 & Rent of land & 0.03 & Rent of land & 0.17 \\
\hline & $\begin{array}{l}\text { Rent of } \\
\text { durables }\end{array}$ & 0.07 & Rent of durables & 0.23 & $\begin{array}{c}\text { Rent of } \\
\text { durables }\end{array}$ & 0.3 & $\begin{array}{c}\text { Rent of } \\
\text { durables }\end{array}$ & 0.37 \\
\hline & Interest & 0.03 & Interest & 0.07 & Interest & 0.07 & Interest & 0.1 \\
\hline & Profit & 0.13 & Profit & 0.13 & Profit & 0.13 & Profit & 0.13 \\
\hline & Other cost & 0.07 & Other cost & 0.07 & Other cost & 0.20 & Other cost & 0.07 \\
\hline & Total cost & 0.67 & Total cost & 1 & Total cost & 1.07 & Total cost & 1.2 \\
\hline
\end{tabular}

Source: Survey data by Taiwan Institute of Economic Research.

Note: Unit USD $/ \mathrm{m}^{3}$ means the cost in US dollars when firms produce hydrogen per cubic meter. We use the exchange rate at 1:30 to transform NTD to USD. 
Scenario IV adopted neo-classical long-run closure for a developed country.

The baseline forecast was conducted over the years 1999-2030, with the energy structure in 2005 presented as follows: crude oil (50.0\%), coal (33.1\%), natural gas $(8.0 \%)$, nuclear energy (7.3\%), hydro-power (1.2\%) and hydrogen energy (0.4\%). Advances in hydrogen technology are encouraged by government policies and modeled herein using three levels_no effort (Scenario I), moderate effort (Scenario II) and strong effort (Scenario III). In Scenario III, strong government effort and significant incentives in industrial sectors have led to annual technology advancement rates of $\mathrm{NG}-\mathrm{H}_{2}$, bio- $\mathrm{H}_{2}$, nuclear- $\mathrm{H}_{2}$ and renewables $-\mathrm{H}_{2}$ at $15 \%$ (means $15 \%$ cost down for hydrogen production). The CES/CET elasticities of bio- $\mathrm{H}_{2}$, other energy sources, primary inputs and transformation are $0.5,0.5,0.4$ and 0.4 , respectively. In Scenarios I and II, all parameters were the same as in Scenario III, but with the progress rate reduced from $15 \%$ to $0 \%$ and $5 \%$, respectively. Scenario IV was elucidated by adjusting Taiwan's economy to an "elastic" one with strong support, such as that in developed countries, with CES elasticities of biohydrogen, other energy sources, primary inputs and transformation at $0.25,1.0,0.8$ and 0.8 , respectively. Table 3 gives an outline of these four scenarios.

\section{Results and discussion}

\subsection{Energy structure and macroeconomy: Scenarios I-III}

Figs. 4(a)-(c) present changes in the energy structure over time in Scenarios I-III, respectively. Since no effort is made to advance the hydrogen production technology, the energy structure in Taiwan changes little over time. The use of crude oil will decline from 50\% in 2005 to $45.8 \%$ in 2030, mainly because of increases in oil price and carbon tax. The use of coal will remain roughly constant at around $33 \%$. While the use of natural gas will increase to compensate for the decline in crude oil supply, the entire economy will still be based on fossil fuels, and the importance of hydrogen energy will be negligible.

If hydrogen technology receives moderate or strong support, then the use of crude oil will drop to $40.5 \%$ or $36.7 \%$, respectively, by 2030. In particular, the use of coal will be reduced to $30.1 \%$ in 2005 according to the value shown in Scenario III because the price of coal will be quite stable. Accordingly, coal will outperform petroleum in the future as the main energy source. With progress in hydrogen production technologies, industrial sectors have incentives to use more hydrogen. In Scenario II, the share of hydrogen will increase to $5.6 \%$ in 2030 . In Scenario III, the hydrogen share will increase to $10.3 \%$, representing a major increase in hydrogen use, but nothing close to fully replacing crude oil or coal.

The real GDP growth rate of Taiwan will be lower in Scenarios II and III than in Scenario I up to 2025, when support will be instituted to promote advances in the industrial hydrogen technology (Scenarios II and III in Table 3), reflecting the investment made in technological development and infrastructure, as well as the depletion of some commonly used resources in the hydrogen sectors during the transition. After 2021, however, hydrogen will replace some fossil fuels, which will be expensive given a high $\mathrm{CO}_{2}$ emission rate, yielding a higher GDP growth rate than that of a petroleum-based economy (Scenario I in Table 4).

One of the main assumed advantages of the transition to hydrogen economy is a major decrease in $\mathrm{CO}_{2}$ emission rate. In 2005, the total amount of emitted $\mathrm{CO}_{2}$ in Taiwan was estimated to be $266.7 \times 10^{6}$ ton. Without countermeasures, this emission rate will increase to $1015 \times 10^{6}$ ton in 2030 . With strong or moderate effort, the $\mathrm{CO}_{2}$ emission will drop to $929 \times$ $10^{6}$ or $990 \times 10^{6}$ ton, respectively, or $2.3 \%$ or $8.5 \%$. However, this emission amount is still about 3.5 times that of 2005 . Restated, even with strong effort to advance technology, the fall in the $\mathrm{CO}_{2}$ emission rate is limited and not necessarily consistent with the target set by the Kyoto Protocol.

Table 3 - Assumptions for four scenarios' design

\begin{tabular}{|c|c|c|c|c|}
\hline & Scenario I & Scenario II & Scenario III & Scenario IV \\
\hline $\begin{array}{l}\text { Economic } \\
\text { structure }\end{array}$ & $\begin{array}{c}\text { Developing economic } \\
\text { structure }\end{array}$ & $\begin{array}{l}\text { Developing economic } \\
\text { structure }\end{array}$ & $\begin{array}{c}\text { Developing economic } \\
\text { structure }\end{array}$ & $\begin{array}{c}\text { Developed economic } \\
\text { structure }\end{array}$ \\
\hline Closure & Keynesian school & Keynesian school & Keynesian school & Classical school \\
\hline Endogenous & Employment & Employment & Employment & Wage rate \\
\hline Variables & Rate of return & Rate of return & Rate of return & Capital stock \\
\hline Exogenous & Wage rate & Wage rate & Wage rate & Employment \\
\hline Variables & Capital stock & Capital stock & Capital stock & Rate of return \\
\hline Elasticities & $\begin{array}{c}\text { CES elasticities of } \\
\text { biohydrogen, other energy } \\
\text { sources, primary inputs, } \\
\text { CET transformation, etc. at. } \\
0.5,0.5,0.4 \text { and } 0.4\end{array}$ & $\begin{array}{c}\text { CES elasticities of } \\
\text { biohydrogen, other energy } \\
\text { sources, primary inputs, } \\
\text { CET transformation, etc. at } \\
0.5,0.5,0.4 \text { and } 0.4\end{array}$ & $\begin{array}{c}\text { CES elasticities of } \\
\text { biohydrogen, other energy } \\
\text { sources, primary inputs, } \\
\text { CET transformation, etc. at } \\
0.5,0.5,0.4 \text { and } 0.4\end{array}$ & $\begin{array}{c}\text { CES elasticities of } \\
\text { biohydrogen, other energy } \\
\text { sources, primary inputs, CET } \\
\text { transformation, etc. at } 0.25 \text {, } \\
1.0,0.8 \text { and } 0.8\end{array}$ \\
\hline Effort & No effort & Moderate effort & Strong effort & Strong effort \\
\hline $\begin{array}{l}\text { Technology } \\
\text { progress rate }\end{array}$ & $\begin{array}{c}\text { Technology progress } \\
\text { rate at } 0 \%\end{array}$ & $\begin{array}{c}\text { Technology progress } \\
\text { rate at } 5 \%\end{array}$ & $\begin{array}{c}\text { Technology progress } \\
\text { rate at } 15 \%\end{array}$ & $\begin{array}{c}\text { Technology progress } \\
\text { rate at } 15 \%\end{array}$ \\
\hline
\end{tabular}


a
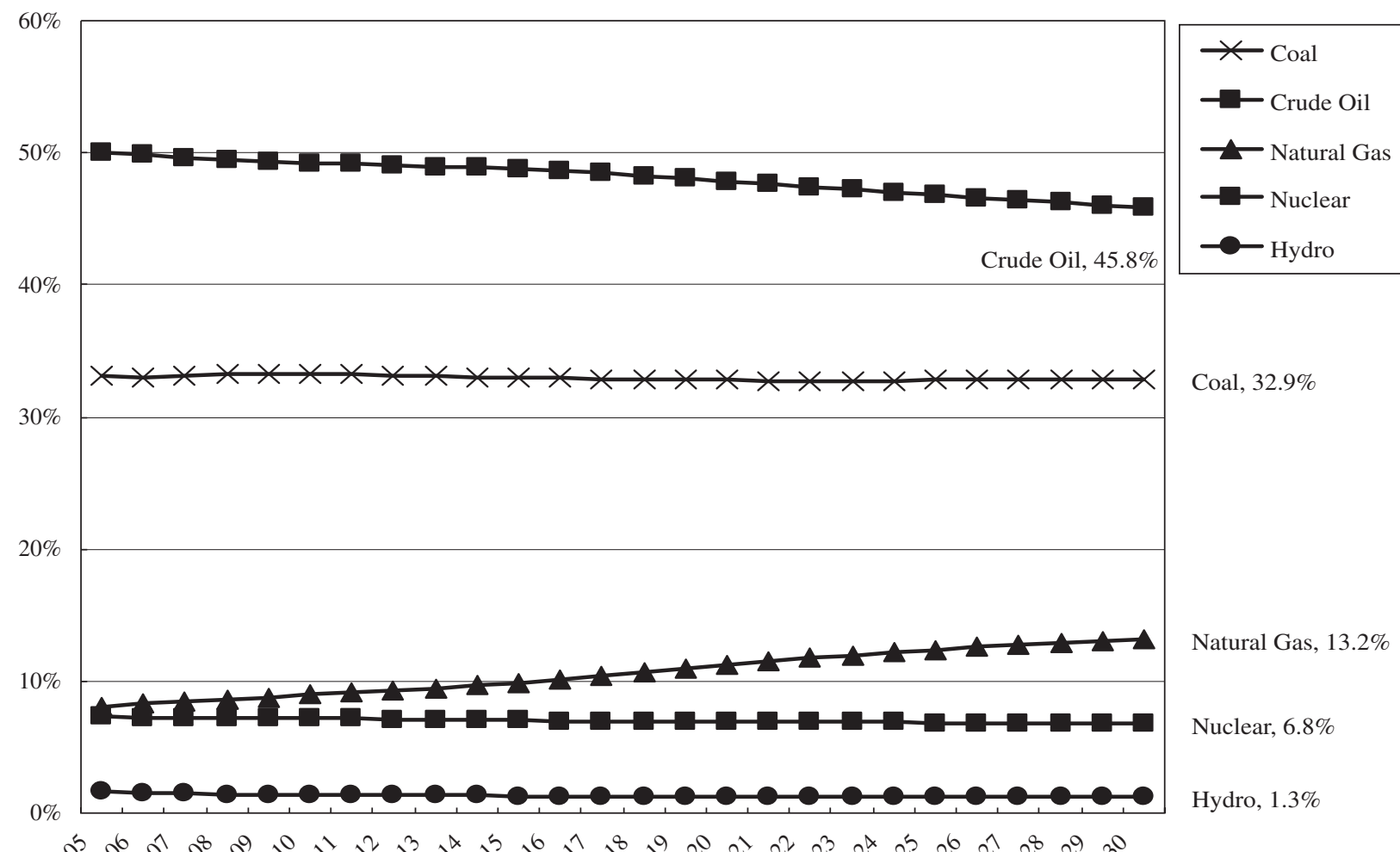

Coal, $32.9 \%$

Natural Gas, $13.2 \%$

Nuclear, $6.8 \%$

Hydro, $1.3 \%$

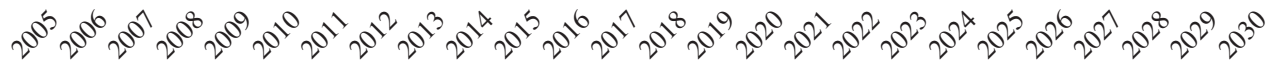

b

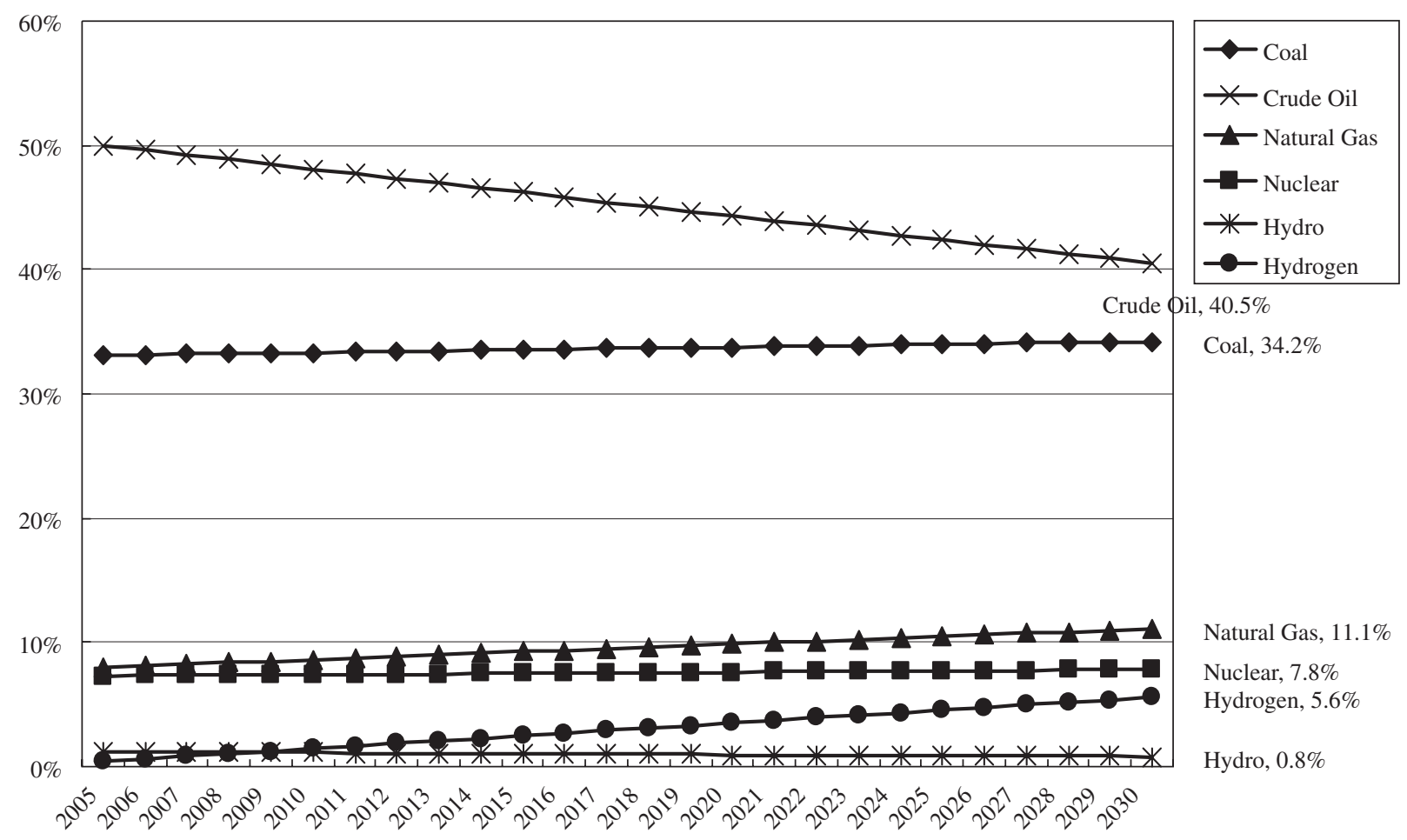

Fig. 4 - (a) Energy structure in Scenario I. Existing economic structure with no support. (b) Energy structure in Scenario II. Existing economic structure with moderate support. (c) Energy structure in Scenario III. Existing economic structure with strong support. 


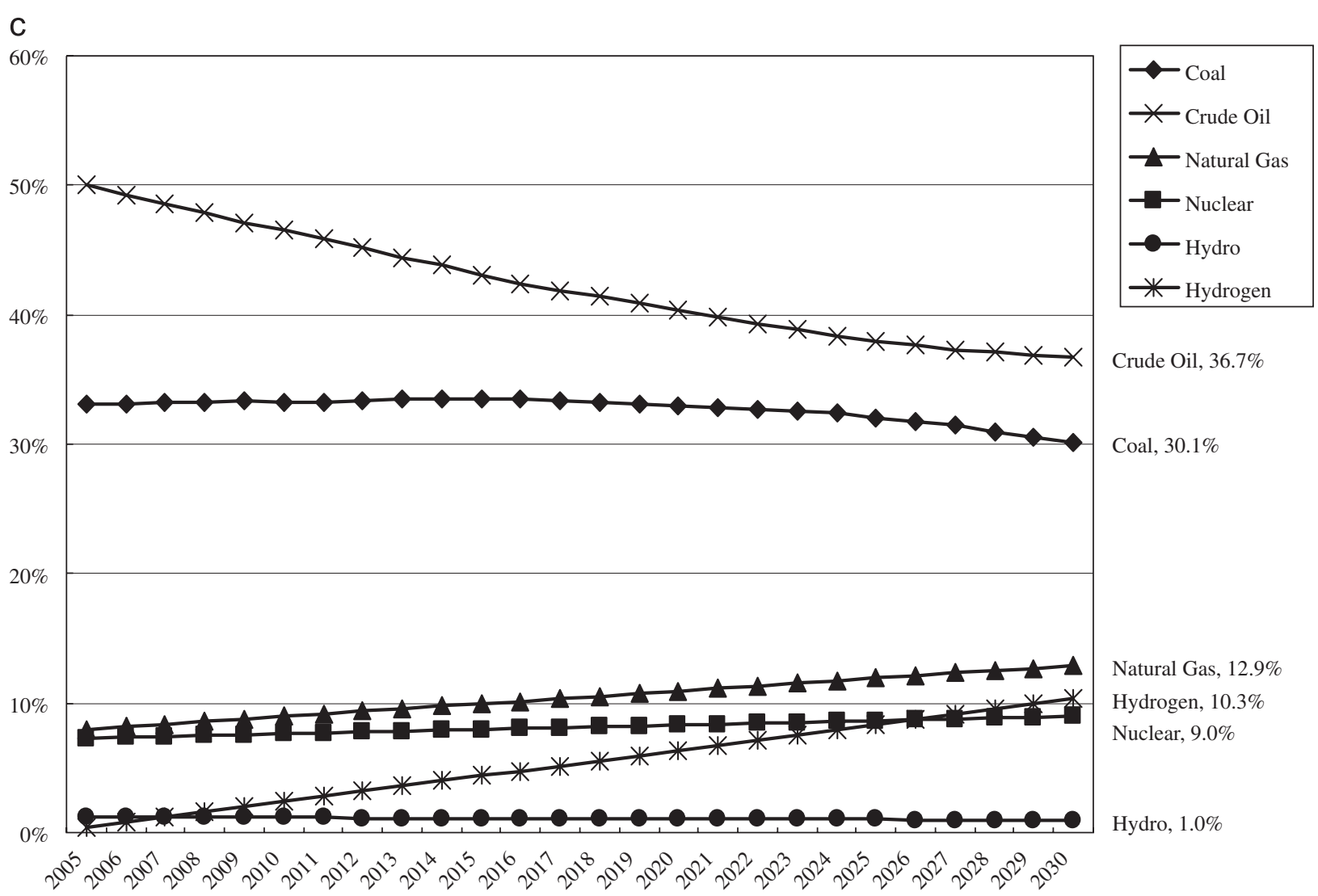

Fig. 4 - (Continued)

Table 4 - Real GDP growth rates (\%) under Scenarios I-III

\begin{tabular}{lccccc}
\hline Year & Scenario I & Scenario II & Scenario III & II-I & III-I \\
\hline 2006 & 5.42 & 4.64 & 4.58 & -0.78 & -0.84 \\
2010 & 6.21 & 5.57 & 5.45 & -0.64 & -0.76 \\
2015 & 5.98 & 5.62 & 5.56 & -0.36 & -0.42 \\
2020 & 5.32 & 5.16 & 5.04 & -0.16 & -0.28 \\
2025 & 5.01 & 5.07 & 5.24 & +0.06 & +0.23 \\
2030 & 4.97 & 5.08 & 5.33 & +0.11 & +0.36 \\
\hline
\end{tabular}

\subsection{Scenario IV: a reformed economy}

As discussed in Section 3.1, a successful transition to a hydrogen economy cannot be achieved in Taiwan only by promoting technological progress. The economic structure of Taiwan must be completely revised. In Scenario IV, Taiwan's economy is considered to be "elastic"-like those of developed countries. In this scenario, all parameters are as in Scenario III, even though different CES elasticities are adopted in the simulation: biohydrogen (0.25), other energy sources (1.0), primary inputs (0.8) and transformation (0.8). Restated, the fossil fuels (petroleum, coal, natural gas) can be easily replaced with hydrogen. In this scenario, a strong effort is made to ensure a high level of technology progress (15\% annually).
Fig. 5 displays the changes in energy structure over time in Scenario IV. With a reformed economy and strong effort, the proportions of crude oil and coal will be reduced to $25.3 \%$ and $23.0 \%$, respectively, in 2030 , with hydrogen in third place among the six main energy sources. Clearly, the use of nuclear energy and that of natural gas will also increase, leveling off at around 2022-2025 and beyond. In contrast, the use of hydrogen will continue. According Chalk [36], the timeline for hydrogen economy for USA may be realized after 2040. Our results show the trend that hydrogen may be the dominant energy source before 2040, and the transition to a hydrogen economy will thus be successful as Chalk [36] outlines. In Scenario IV the $\mathrm{CO}_{2}$ emission will drop to $563 \times 10^{6}$ ton or $44.5 \%$ compared with Scenario I (Table 5). It means reformation 


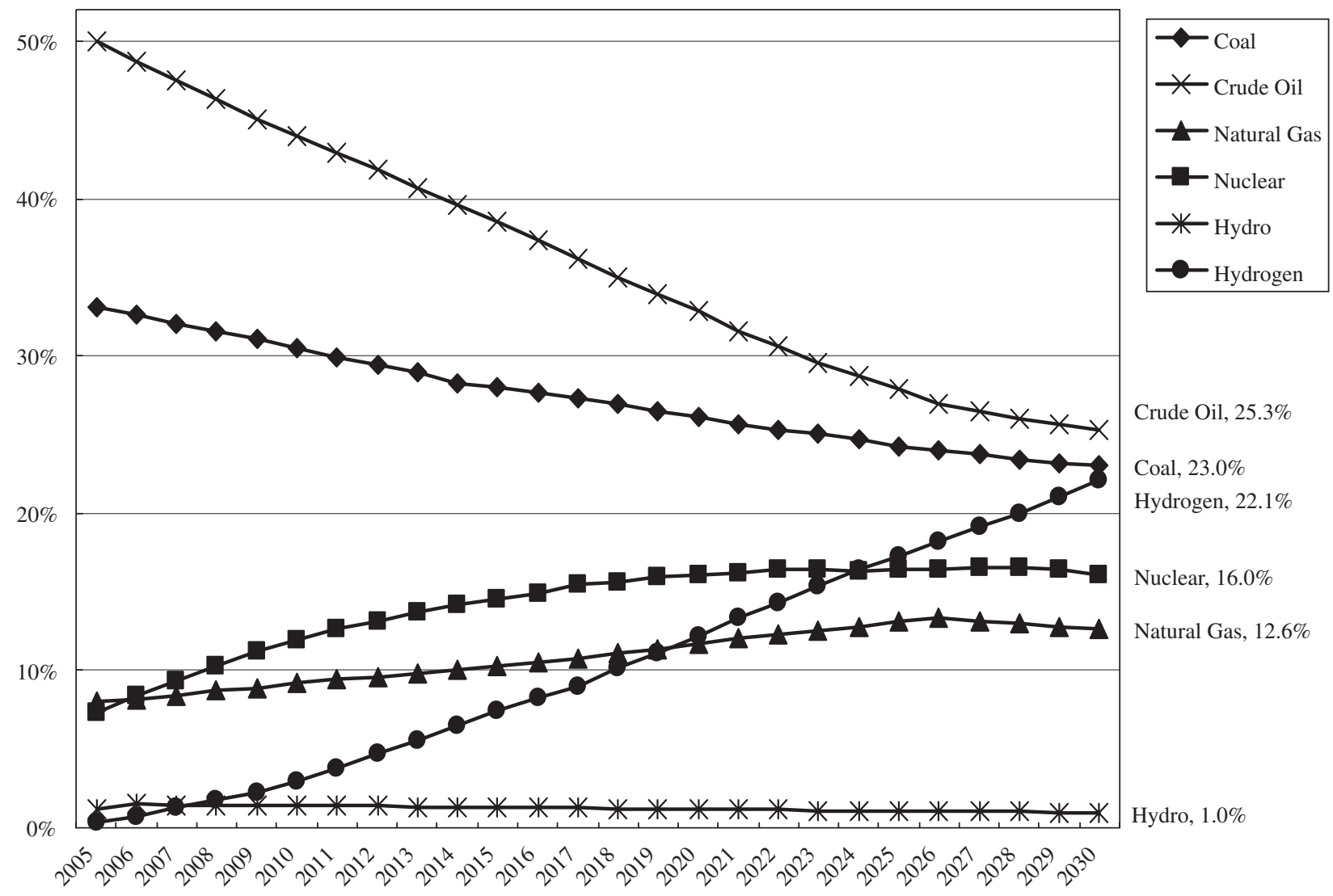

Fig. 5 - Energy structure in Scenario IV. Reformed economic structure with strong support.

\section{Table 5 - Carbon dioxide emission rates under Scenarios I-IV}

\begin{tabular}{cccccccc}
\hline \multirow{2}{*}{ Year } & \multicolumn{7}{c}{$\mathrm{CO}_{2}$ emission $\left(10^{6}\right.$ ton) } \\
\cline { 2 - 8 } & Scenario I & Scenario II & Scenario III & Scenario IV & II-I & III-I & IV-I \\
\hline 2006 & 266.7 & 266.4 & 265.6 & 245.2 & $-0.3(-0.1 \%)$ & $-1.1(-0.4 \%)$ & $-21.5(-8.1 \%)$ \\
2010 & 353 & 350 & 345 & 274 & $-3.0(-0.9 \%)$ & $-8.1(-2.3 \%)$ & $-79.2(-22.5 \%)$ \\
2015 & 449 & 443 & 430 & 322 & $-5.4(-1.2 \%)$ & $-18.8(-4.2 \%)$ & $-127(-28.3 \%)$ \\
2020 & 597 & 587 & 563 & 387 & $-10.0(-1.7 \%)$ & $-34.0(-5.7 \%)$ & $-210(-35.2 \%)$ \\
2025 & 778 & 763 & 730 & 468 & $-15.7(-2.0 \%)$ & $-48.3(-6.2 \%)$ & $-311(-40.0 \%)$ \\
2030 & 1015 & 990 & 929 & 563 & $-25.7(-2.5 \%)$ & $-86.3(-8.5 \%)$ & $-452(-44.5 \%)$ \\
\hline
\end{tabular}

of economic structure is the key point of the hydrogen economy.

The reformation of the economic structure is to discourage the use of petroleum and strongly encourage the use of hydrogen. Therefore, barriers to hydrogen imports should be removed, hydrogen commodity imports should be subsidized, investments should be made in the hydrogen supply chain, new demand should be created for hydrogen applications, the expansion of petroleum-related industries should be limited and carbon taxes and energy taxes should be levied. Without a complete reformation of the economic structure, the transition to hydrogen economy will not be achievable before 2040.

\subsection{Role of biohydrogen}

In Scenarios II or III, the production rate of hydrogen will initially increase; $\mathrm{NG}-\mathrm{H}_{2}$ will have the highest production rate because of the ease of producing hydrogen using existing facilities whenever needed. However, the NG pathway will be replaced by alternatives in 2010-2015 because of cheaper production costs and the advantage of producing no $\mathrm{CO}_{2}$ by the other three methods. In Scenario III, the rates of increase of hydrogen production by bio- $\mathrm{H}_{2}$, nuclear- $\mathrm{H}_{2}$ and renewables- $\mathrm{H}_{2}$ will reach $6.1 \%, 3.8 \%$ and $5.5 \%$, respectively, in 2025 , with bio- $\mathrm{H}_{2}$ leading the other two. 
Table 6 - Percentage changes of hydrogen industries production under Scenarios II-IV

\begin{tabular}{|c|c|c|c|c|c|c|c|c|c|c|c|c|}
\hline \multirow[t]{2}{*}{ Year } & \multicolumn{4}{|c|}{ Scenario II } & \multicolumn{4}{|c|}{ Scenario III } & \multicolumn{4}{|c|}{ Scenario IV } \\
\hline & $\begin{array}{c}\text { NG } \\
\text { hydrogen }\end{array}$ & Biohydrogen & $\begin{array}{c}\text { Nuclear } \\
\text { hydrogen }\end{array}$ & $\begin{array}{c}\text { Other } \\
\text { renewable }\end{array}$ & $\begin{array}{c}\text { NG } \\
\text { hydrogen }\end{array}$ & Biohydrogen & $\begin{array}{c}\text { Nuclear } \\
\text { hydrogen }\end{array}$ & $\begin{array}{c}\text { Other } \\
\text { renewable }\end{array}$ & $\begin{array}{c}\text { NG } \\
\text { hydrogen }\end{array}$ & Biohydrogen & $\begin{array}{c}\text { Nuclear } \\
\text { hydrogen }\end{array}$ & $\begin{array}{c}\text { Other } \\
\text { renewable }\end{array}$ \\
\hline 2006 & 1.2 & 0.3 & 0.1 & 0.3 & 4.5 & 2.1 & 1.1 & 1.8 & 13.4 & 12.2 & 10.5 & 11.3 \\
\hline 2010 & 3.2 & 0.7 & 0.3 & 0.6 & 4.8 & 3.4 & 1.8 & 2.9 & 11.2 & 12.7 & 11.3 & 12.1 \\
\hline 2015 & 2.1 & 1.2 & 0.5 & 1.0 & 5.1 & 4.2 & 2.1 & 3.9 & 6.3 & 10.7 & 9.9 & 10.2 \\
\hline 2020 & 2.3 & 1.4 & 0.8 & 1.2 & 3.8 & 5.3 & 3.2 & 4.8 & 3.4 & 9.6 & 8.6 & 9.1 \\
\hline 2025 & 1.5 & 1.8 & 0.9 & 1.6 & 3.2 & 6.1 & 3.8 & 5.5 & 0.4 & 8.8 & 7.6 & 8.5 \\
\hline 2030 & 1.3 & 2.1 & 1.1 & 1.9 & 2.9 & 4.3 & 3.2 & 4.1 & -1.3 & 8.2 & 6.3 & 7.9 \\
\hline
\end{tabular}

\section{Table 7 - Percentage changes in commodity price of hydrogen-related industries under Scenarios II-IV}

\begin{tabular}{|c|c|c|c|c|c|c|c|c|c|c|c|c|}
\hline \multirow[t]{2}{*}{ Year } & \multicolumn{4}{|c|}{ Scenario II } & \multicolumn{4}{|c|}{ Scenario III } & \multicolumn{4}{|c|}{ Scenario IV } \\
\hline & $\begin{array}{c}\text { NG } \\
\text { hydrogen }\end{array}$ & Biohydrogen & $\begin{array}{c}\text { Nuclear } \\
\text { hydrogen }\end{array}$ & $\begin{array}{c}\text { Other } \\
\text { renewable }\end{array}$ & $\begin{array}{c}\text { NG } \\
\text { hydrogen }\end{array}$ & Biohydrogen & $\begin{array}{c}\text { Nuclear } \\
\text { hydrogen }\end{array}$ & $\begin{array}{c}\text { Other } \\
\text { renewable }\end{array}$ & $\begin{array}{c}\text { NG } \\
\text { hydrogen }\end{array}$ & Biohydrogen & $\begin{array}{l}\text { Nuclear } \\
\text { hydrogen }\end{array}$ & $\begin{array}{c}\text { Other } \\
\text { renewable }\end{array}$ \\
\hline 2006 & 3.2 & -0.5 & -0.1 & -0.3 & 4.1 & -0.7 & -0.4 & -0.6 & 12.8 & -3.4 & -1.9 & -2.1 \\
\hline 2010 & 2.3 & -1.2 & -0.4 & -0.8 & 2.7 & -1.9 & -1.0 & -1.7 & 3.2 & -5.4 & -5.0 & -4.3 \\
\hline 2015 & 1.4 & -1.5 & -0.6 & -1.1 & 2.4 & -2.0 & -1.2 & -1.8 & 2.5 & -5.0 & -5.5 & -6.7 \\
\hline 2020 & 1.5 & -1.7 & -1.0 & -1.4 & 2.5 & -2.4 & -1.3 & -2.0 & 2.3 & -4.7 & -5.1 & -5.3 \\
\hline 2025 & 1.6 & -1.9 & -0.9 & -1.5 & 2.9 & -3.5 & -1.6 & -3.1 & 3.1 & -6.1 & -5.6 & -5.0 \\
\hline 2030 & 1.4 & -1.8 & -1.0 & -1.4 & 2.7 & -3.1 & -2.1 & -2.8 & 3.7 & -6.3 & -6.0 & -6.2 \\
\hline
\end{tabular}


In Scenario IV, with a reformed economy, hydrogen can easily replace fossil fuels, markedly increasing the hydrogen production rate (Fig. 5). As Table 6 indicates, without delay, the increase in all hydrogen production sub-sectors will exceed $10 \%$, with $\mathrm{NG}-\mathrm{H}_{2}$ ranking first (as expected). However, since progress in production technologies is assumed to be significant, the productions of hydrogen using other subsectors all increase to a high level. Then, the rate of increase declines over time. In 2030, production through NG- $\mathrm{H}_{2}$ begins to drop, while the growth through bio- $\mathrm{H}_{2}$, nuclear- $\mathrm{H}_{2}$ and renewables- $\mathrm{H}_{2}$ will be $8.2 \%, 6.3 \%$ and $7.9 \%$, respectively, in 2030.

Table 7 presents changes in energy prices in Scenarios II-IV. The prices of natural gas continue to increase over time, reflecting the increase in the prices of fossil fuels. However, the prices of bio- $\mathrm{H}_{2}$, nuclear- $\mathrm{H}_{2}$ and renewables- $\mathrm{H}_{2}$ drop over time, reaching $6.3 \%, 6.0 \%$ and $6.2 \%$ of those in 2030 .

Clearly, in all scenarios, all hydrogen production sub-sectors without $\mathrm{CO}_{2}$ emission contribute almost equally to the hydrogen production sector, since advances in their corresponding technologies are the same over time. Restated, when petroleum runs out and $\mathrm{CO}_{2}$ emission becomes a major environmental concern, production in all hydrogen sub-sectors will start compensating for the demand-supply gap of fossil fuels. However, in later stages of development, the competition among bio- $\mathrm{H}_{2}$ and nuclear- $\mathrm{H}_{2}$ and renewables- $\mathrm{H}_{2}$ determines their role in the hydrogen economy from 2040. Reduction in costs due to technological progress will be essential toward phasing out non-competitive players in the field.

\section{Summary}

This study presents an economy-wide analysis of how technology advances and how an improvement in the economic structure is accelerating Taiwan's transition to a hydrogen economy before 2030. We utilized a model, called "Taiwan general equilibrium model-energy, for hydrogen (TAIGEM-EH)", as the forecast tool to evaluate the critical factors that affect the economic growth rates, $\mathrm{CO}_{2}$ emission rates and the possible, adverse effects of inertial barriers of increases in the price of oil and the difficulty of energy substitution in the present economic structure.

Simulation results showed that, when no effort is made to advance the hydrogen production technology, the energy structure in Taiwan will remain almost unchanged over time, with crude oil and coal the primary energy sources up to 2030. When the hydrogen production technology receives moderate or strong support, then the use of crude oil will drop to $40.5 \%$ or $36.7 \%$, respectively, by 2030 , the corresponding share of hydrogen will increase to $5.6 \%$ or $10.3 \%$ and the reduction in $\mathrm{CO}_{2}$ emission rate will be merely $2.3 \%$ or $8.5 \%$. Taiwan cannot achieve a successful transition to the hydrogen economy by solely relying on advances in hydrogen production technology. Scenario IV shows that the $\mathrm{CO}_{2}$ emission rate will drop to $563 \times 10^{6}$ ton or $44.5 \%$ compared with Scenario I, revealing the main benefits that Taiwan will obtain by transforming into a hydrogen economy. Reformation of economic structure together with a strong support for hydrogen technology progress is shown to be essential toward accomplishing a transition to the hydrogen economy.

Among hydrogen production technologies, natural gas dominates the initial stage because of the ease in expanding existing facilities. From 2010 to 2015 and onwards, the production pathway of producing no $\mathrm{CO}_{2}$ becomes dominating. When petroleum runs out and $\mathrm{CO}_{2}$ emission becomes a major environmental concern, all hydrogen production subsectors will be utilized initially to compensate for the demand-supply gap of fossil fuels. However, in the later development stages, the competition among bio- $\mathrm{H}_{2}$ and nuclear- $\mathrm{H}_{2}$ and renewables- $\mathrm{H}_{2}$ determines their role in the hydrogen economy from 2040. Reduction in costs due to technological progress will be essential toward phasing out non-competitive players in the field. Scenario IV predicts that a successful transition to the hydrogen economy requires not only a substantial reduction of hydrogen production cost, but also a reformation of Taiwan's economic structure. Scenario IV also shows that the cost of hydrogen should down to an incredible low level (with 15\% cost down in Table 8). It means that the hydrogen should not be a major energy in the world

Table 8 - Cost down effect in three kinds of hydrogen production

\begin{tabular}{|c|c|c|c|c|c|}
\hline & 2010 & 2015 & 2020 & 2025 & 2030 \\
\hline \multicolumn{6}{|c|}{ Strong effort ( $15 \%$ cost down) } \\
\hline Bio- $\mathrm{H}_{2}$ & 0.444 & 0.197 & 0.087 & 0.039 & 0.017 \\
\hline Nuclear- $\mathrm{H}_{2}$ & 0.473 & 0.210 & 0.093 & 0.041 & 0.018 \\
\hline Renewables- $\mathrm{H}_{2}$ & 0.532 & 0.236 & 0.105 & 0.047 & 0.021 \\
\hline \multicolumn{6}{|c|}{ Median effort ( $5 \%$ cost down) } \\
\hline Bio- $\mathrm{H}_{2}$ & 0.774 & 0.599 & 0.463 & 0.358 & 0.277 \\
\hline Nuclear- $\mathrm{H}_{2}$ & 0.825 & 0.639 & 0.494 & 0.382 & 0.296 \\
\hline Renewables- $\mathrm{H}_{2}$ & 0.929 & 0.718 & 0.556 & 0.43 & 0.333 \\
\hline
\end{tabular}


energy market in the next 20-30 years. It reminds us that hydrogen is a suitable alternative energy but it still has a long way to go. We should develop different kinds of alternative energies to try to replace fossil fuels, not only hydrogen.

R E F E R E N C E S

[1] Jones MD. Towards a hydrogen economy. Presentation to the IEA renewables energy working party seminar, Paris; 2003.

[2] Simbolotti G. Is hydrogen an energy product. In: Energy statistics working group meeting, IEA, Paris, 2004.

[3] Das D, Veziroglu TN. Hydrogen production by biological processes: a survey of literature. Int J Hydrogen Energy 2001;26:13-28.

[4] Levin DB, Pitt L, Love M. Biohydrogen production: prospects and limitations to practical application. Int J Hydrogen Energy 2004;29(2):173-85.

[5] Fatjh DM. Hydrogen from various biomass species via pyrolysis and steam gasification processes. Energy Sources 2006;28(3):245-52.

[6] Spath PL, Lane JM, Mann MK, Amos WA. Update of hydrogen from biomass-determination of the delivered cost of hydrogen. Milestone Report for the U.S. Department of Energy' Hydrogen Program Process Analysis Task, National Renewable Energy Laboratory; 2000.

[7] Maniatis K. Pathways for the production of bio-hydrogen: opportunities and challenges. In: Towards hydrogen, IEA, Paris, 3 March 2003.

[8] Dixon PB, Parmenter BR, Sutton J, Vincent DP. ORANI: a multisectoral model of the Australian economy. Amsterdam: North-Holland; 1982.

[9] Dixon PB, Rimmer MT. Dynamic general equilibrium modeling for forecasting and policy: a practical guide and documentation of MONASH. Amsterdam: North-Holland; 2002.

[10] Parmenter BR. Forecasting and policy analysis with the MONASH model. Paper prepared for the international symposium on economic modeling. Italy: Bologna; 1995.

[11] Lee DH, Lee DJ. Bio-fuel economy and biohydrogen competition. Energy\&Fuels 2007, in press, doi:10.1021/ef700288e.

[12] Hsu SH, Lin HC, Lee DH. An economy-wide analysis of policy responses of Taiwan to stabilize $\mathrm{CO}_{2}$ emissions. In: ETSAP technical conference of Energy Models Users' Group: global and regional energy modeling, 4-7 April, 2005. Summary and proceedings, Taipei, Taiwan, 2005.

[13] Hsu SH, Chang CC, Lee DH, Ziang YZ, Lin HC. A post simulation for foot-and-mouth disease in Taiwan. In: AAEA, 2005 annual meeting, Rhode Island Convention Center, One Sabin St, Providence, RI 02903, USA, 2005.

[14] Li PC, Hsu SH, Huang CH, Lin HH. Baseline forecasting for greenhouse gas reductions in Taiwan: a dynamic CGE analysis. In: Chang CC, Shaw DG, Mendelsohn R, editors. Global warming and the Asian Pacific. Cheltenham, UK: Edward Elgar; 2003.

[15] Lee DJ, Lee DH. Biohydrogen and hydrogen economy. In: 2006 international biohydrogen production technologies conference, Harbin, China, January 13-15 2006.

[16] Lee DH, Hsu SH. An economy-wide analysis for hydrogen economy in Taiwan. In: World hydrogen technologies con- vention 2005, Nanyang University, Singapore, October 12-15 2005.

[17] Powell AA, Gruen FHG. The constant elasticity of transformation production frontier and linear supply system. Int Econ Rev 1968;9(3):315-28.

[18] Arrow KJ, Chenery HB, Minhas BS, Solow RM. Capital-labor substitution and economic efficiency. Rev Econ Stat 1961;43:225-50.

[19] Armington PS. A theory of demand for products distinguished by place of production. IMF Staff Pap 1969;16:159-78.

[20] ABARE. The MEGABARE model: interim documentation. AGPS, Canberra; 1996.

[21] DGBAS. Taiwan input-output tables. Directorate-General of Budget 1976-2001, Accounting and Statistics, Taiwan, ROC; 2005.

[22] Liss WE, Richards M. Development of a natural gas to hydrogen fuel station. In: Proceedings of the 2002 U.S. DOE hydrogen program review NREL/CP-610-32405, Des Plaines, Il, USA: Gas Technology Institute; 2002.

[23] Schmidt DD, Gunderson JR. Opportunities for hydrogen: an analysis of the application of biomass gasification to farming operations using microturbines and fuel cells. Energy and Environmental Research Center. University of North Dakota; 2000.

[24] Aaron TM. Low cost hydrogen production platform. In: Cooperative agreement, DE-FC36-01G011004. Tonawanda, NY, Wakefield, RI, Lockport, NY: Team Praxair, BoothroydDewhurst, Diversified Manufacturing. DOE hydrogen annual review meeting, 2000.

[25] Padró CEG, Putsche V. Survey of the economics of hydrogen technologies, National Renewable Energy Laboratory, United States Department of Energy, Washington, DC; 2003.

[26] USDOC. Fuel cell vehicles: race to a new automotive future. Office of Technology Policy, Technology Administration, US Department of Commerce, Washington, DC; 2003.

[27] Eaves S, Eaves J. A cost comparison of fuel-cell and battery electric vehicles. Charlestown, RI, Mesa, AZ: Eaves Devices, Arizona State University-East; 2002.

[28] Romm J. Reviewing the hydrogen fuel and freedom car initiatives. In: The hype about hydrogen. The House Science Committee. Island Press; 2004.

[29] Morrison JM. Technology development and validation of industrial fuel cell vehicles-phases II/III. Southeastern Technology Center: Augusta, GA 30906-3381; 2004.

[30] Jacobson MZ, Colella WG, Golden DM. Cleaning the air and improving health with hydrogen fuel cell vehicles. In: Validation of an integrated system for a hydrogen-fueled power park; 2004.

[31] Carlson EJ, Kopf P, Sinha J, Sriramulu S, Yang Y. Cost analyses of fuel cell stack/systems. DOR Hydrogen Program FY 2005 Progress Report, United States Department of Energy, Washington, DC; 2005.

[32] TPC. The analytic table for cost of different power generation. Taiwan Power Company, Taiwan, ROC; 2001.

[33] TPC. The analytic table for cost of power sales. Taiwan Power Company, Taiwan, ROC; 2001.

[34] DGBAS. Statistical yearbook. Taiwan, ROC: DirectorateGeneral of Budget, Accounting and Statistics; 2005.

[35] EIA. International energy outlook; 2006.

[36] Chalk S. Technologies for carbon capture and storage and hydrogen and electricity production. In: Hydrogen, fuel cells and infrastructure technologies program, U.S.D.O.E., 2003. 